\title{
Killer whale predation on bluefin tuna: exploring the hypothesis of the endurance-exhaustion technique
}

\author{
C. Guinet ${ }^{1, *}$, P. Domenici ${ }^{2,3}$, R. de Stephanis ${ }^{4}$, L. Barrett-Lennard ${ }^{5}$, J. K. B. Ford ${ }^{6}$, \\ P. Verborgh ${ }^{1,4}$ \\ ${ }^{1}$ CEBC-CNRS, 79360 Villiers en Bois, France \\ ${ }^{2}$ IAMC-CNR, and ${ }^{3}$ International Marine Centre, Località Sa Mardini,Torregrande (Or) 09072 Italy \\ ${ }^{4}$ CIRCé, C/Cabeza de Manzaneda 3, Algeciras-Pelayo, 11390 Cadiz, Spain \\ ${ }^{5}$ Vancouver Aquarium Marine Science Centre, Box 3232, Vancouver, British Columbia V6B 3X8, Canada \\ ${ }^{6}$ Fisheries and Oceans Canada, Pacific Biological Station, Nanaimo, British Columbia V9T 6N7, Canada
}

\begin{abstract}
Killer whales Orcinus orca occur in the area of the Strait of Gibraltar, where they prey on migrating bluefin tuna Thunnus thynnus. In the spring, killer whales were observed to chase tuna for up to 30 min at a relatively high sustained speed $\left(3.7 \pm 0.2 \mathrm{~m} \mathrm{~s}^{-1}\right)$ until they captured them. Using simple models based on previous locomotor performance data on killer whales and thunnids, we investigated the hypothesis that killer whales push tuna beyond their aerobic limits to exhaust and capture them. To test this hypothesis, the endurance of bluefin tuna was estimated from data on maximum burst and aerobic swimming available for bluefin and yellowfin tuna $T$. albacares. The endurance performance of killer whales was evaluated on the basis of the maximal rate of oxygen uptake during exercise $\left(V_{\mathrm{O}_{2} \max }\right)$. We modelled the maximum aerobic power output for a killer whale according to swimming speed using a $V_{\mathrm{O}_{2} \max }$ ranging between 20 and $30 \mathrm{ml} \mathrm{O}_{2} \mathrm{~kg}^{-1} \mathrm{~min}^{-1}$. The output of this model was compared to the observed sustained swimming speed of killer whales chasing prey over long durations. Our results support the hypothesis that killer whales may use an endurance-exhaustion technique to catch small to medium sized (up to 0.8 to $1.5 \mathrm{~m}$ ) bluefin tuna, while larger tuna may be inaccessible to killer whales unless they use cooperative hunting techniques or benefit through depredation of fish caught on long lines, drop lines or trap nets.
\end{abstract}

KEY WORDS: Killer whales $\cdot$ Bluefin tuna $\cdot$ Predation $\cdot$ Endurance $\cdot$ Swimming speed

Resale or republication not permitted without written consent of the publisher

\section{INTRODUCTION}

Killer whales Orcinus orca have one of the most diverse diets among all marine predators, feeding on many prey types including fishes, squids, pinnipeds, cetaceans and seabirds (Heyning \& Dahlheim 1988, Guinet 1992). Killer whales employ a number of different feeding tactics, invariably involving locomotion, to suit the characteristics of their prey. Therefore, an evaluation of locomotor ability relative to that of their prey may be fundamental for understanding the specific feeding tactics used by this predator.
Large aquatic vertebrates such as killer whales show poor turning rates, turning angles and acceleration performances compared to small vertebrates (Domenici 2001). This implies that they may be at a disadvantage when trying to capture small prey in brief strike-escape interactions in which prey are attacked by a bursting predator. To overcome this limitation, killer whales often resort to alternative tactics to capture smaller prey, including group hunting, the use of weapons (e.g. tail slaps; Domenici et al. 2000), pinwheel manoeuvres (Maresh et al. 2004) and other behavioural tactics (summarised by Maresh et al. 
2004). On the other hand, sustained swimming speeds increase with size (Videler 1993). Therefore, at least potentially, an additional tactic for large predators would be to chase prey that are smaller than they are, to the point of exhaustion. This is only possible if the predators are able to 'lock on' to a single prey individual with sight, passive hearing or echolocation, which requires that the pursuit take place in a relatively open environment where refuges are not available (Domenici 2003). In other words, while many types of predator-prey interactions are based on burst (anaerobically powered) swimming with fast starts (Domenici 2001), it is possible that in certain environments (e.g. open sea), long chases based on aerobic swimming of the chaser may occur. In these cases, the relative aerobic performance of predator and prey would be fundamental in determining the outcome of the interaction.

Bluefin tuna Thunnus thynnus are among the prey species attacked by killer whales (De Stephanis 2004). The relative swimming abilities of killer whales and tuna are relevant for understanding the basis of their interactions. Swimming by killer whales is highly efficient (Fish 1998), incorporating dorso-ventral bending of the posterior third of the body in conjunction with pitching of the flukes (Fish 1993). This locomotor pattern has been categorised as carangiform with lunatetail or thunniform swimming (Fish et al. 1988) and is typical of some of the fastest marine vertebrates. Compared to other cetaceans, killer whales show the highest thrust power and the lowest drag coefficient as well as relatively high manoeuvrability (Fish 2002).

Tuna are also extremely fast swimmers and migrate over long distances (Altringham \& Shadwick 2001, Block \& Stevens 2001). They have a number of physiological and biochemical adaptations that lead to a metabolic capacity exceeding that of other fishes, such as an increased heart size, large gill surface area, high blood oxygen-carrying capacity and elevated haematocrit (Korsmeyer et al. 1996, Brill \& Bushnell 2001). Tuna also possess high haemoglobin levels and elevated capillarity in their aerobic muscles (Brill 1996). Biochemical correlates of high energy turnover include a high mitochondrial density, elevated levels of aerobic and anaerobic enzymes and a high tissue buffering capacity (Dickson 1994). As a result, tuna have high glycolytic capacity (Bushnell \& Brill 2001) and high anaerobic capacity, and they can repay $\mathrm{O}_{2}$ debt relatively quickly (Brill 1987, Korsmeyer \& Dewar 2001). Tuna also have a relatively high proportion of aerobic locomotor (red) muscle, and their ability to elevate their body temperature may also contribute to high muscle power (Altringham \& Shadwick 2001, Block \& Stevens 2001).

Tuna also possess a suite of morphological adaptations linked to enhanced swimming performance. Adaptations for sustained swimming in tuna include a fusiform body shape to reduce drag, fin grooves to increase streamlining, a high-aspect-ratio tail with a narrow caudal peduncle with lateral keels, high body rigidity to minimise side-movements and therefore drag, and finlets along the trailing edges of the body (Webb 1984, Block \& Stevens 2001). However, some of these characteristics (such as body shape and rigidity) are disadvantageous for manoeuvring (Altringham \& Shadwick 2001), and indeed, yellowfin tuna Thunnus albacares have the largest known turning radius of all fish measured thus far (Blake et al. 1995, Domenici 2001). Similarly, they are expected to show relatively low acceleration performance as a result of their small posterior surface area (Webb 1984), although this has not been measured.

The high maximum aerobic metabolic rate in tuna may be an adaptation to repay oxygen debt relatively quickly while maintaining relatively high (3 to 5 lengths $\mathrm{s}^{-1}$ ) swimming speeds, since the pelagic environment does not provide places to hide and rest while recovering from exercise (Bushnell \& Brill 1991). However, repeated field observations have indicated that killer whales are capable of catching migrating bluefin tuna in the area of the Strait of Gibraltar (De Stephanis 2004). Therefore, it is possible that despite the relatively high swimming performance of tuna and the ability of repaying oxygen debt, killer whales are able to chase these fish to the point of exhaustion. To test this hypothesis, we estimated the speeds of killer whales during chases and compared these speeds to theoretical estimates of sustained swimming performance in tuna and killer whales based on previously published data. This provides a theoretical framework for examining tuna-killer whale interactions in terms of their relative swimming performance.

\section{MATERIALS AND METHODS}

Study area and surveys. The study area was located in the Cape Trafalgar area of the Mediterranean coast of Spain, near the town of Barbate (Fig. 1). This sector is characterised by an extended area of shallow waters with a maximum depth reaching $100 \mathrm{~m}$ at about 10 to $15 \mathrm{~km}$ offshore. We searched for killer whales from a research vessel throughout the months of April and May from 2002 to 2004. Searches were conducted with no predefined track but were designed to cover the whole study sector. The sampling strategy was identical throughout the survey period. The area was surveyed by the research vessel at an average speed of $2.2 \mathrm{~m} \mathrm{~s}^{-1}$ (5.3 knots). The observers were positioned on an observation platform $4 \mathrm{~m}$ above sea level from which killer whales could be seen up to 3 nautical miles ( $\mathrm{n}$ miles) away. One or 2 trained observers 


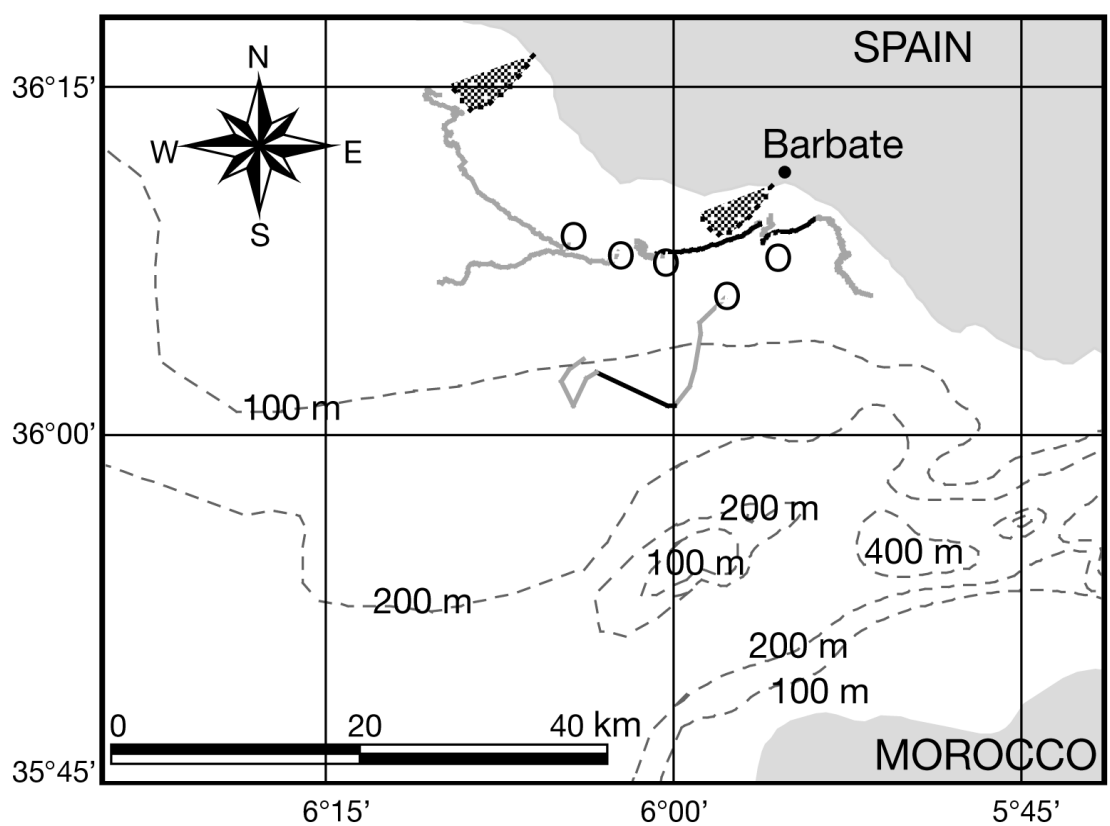

Fig. 1. Track lines of the 5 killer whale encounters in the Barbate area ( $\bullet$, Strait of Gibraltar. O: locations where killer whales were first sighted: grey lines: tracks of killer whales not chasing bluefin tuna; black lines: tracks associated with fast swimming chases of bluefin tuna. The shaded areas indicate the locations of trap nets

occupied the observation lookout post in $1 \mathrm{~h}$ shifts during daylight. Observers, assisted with $8 \times 50$ binoculars, searched for whales by scanning up to $90^{\circ}$ on each side of the vessel's heading. The mean water temperature (at a $1 \mathrm{~m}$ depth) was $16^{\circ} \mathrm{C}$, and bottom depth was recorded every $20 \mathrm{~min}$.

The geographic position of the ship was recorded each minute on the ship's computer from a GPS navigation system interfaced with the software Logger 2000 (version 2.20, International Fund for Animal Welfare, IFAW). Searching effort stopped when a group of killer whales was encountered.

Killer whale behaviour and predation on tuna. Killer whale behaviour was monitored as the animals were followed at distances of approximately 100 to $200 \mathrm{~m}$ from the research vessel. Every $4 \mathrm{~min}$, a scan was conducted, and the general activity of the whales (resting, travelling, foraging, chasing, milling, socialising) was recorded while their track was monitored continuously with the Logger software. Periods of very rapid swimming involved consistent and dramatic modifications in swimming and breathing behaviour. When swimming rapidly, the whales exposed most of their body every 20 to $30 \mathrm{~s}$ to breathe. When chasing tuna, killer whale swimming speed exceeded the survey vessel's maximum speed of $3.75 \mathrm{~m} \mathrm{~s}^{-1}$ (9 knots). However, despite increasing distance between the killer whales and the vessel during the chasing period, we were able to track them as they maintained their heading in a nearly constant direction and leapt out of the water. Therefore, observation of the whales did not stop, and the observer was able to evaluate the duration of the chase as well as the distance covered by the whales. These active swimming periods ended in an abrupt change of behaviour, with killer whales switching to a resting-milling mode in a restricted location where they were later joined by the research vessel. This allowed a reasonably precise estimation of the location where the active swimming behaviour ended. Predation on tuna was confirmed when at least one of the killer whales was observed carrying a tuna (or parts) in its mouth when surfacing. On these occasions, we estimated the swimming speed as the linear distance (m) between the locations where the active swimming started and ended divided by the time elapsed. As a result, the estimated swimming speed is likely to be an underestimate of the actual swimming speed.

Endurance estimates of bluefin tuna swimming speeds. The study of swimming performance in tuna has been limited by their large size and the difficulty of keeping them in captivity. Nevertheless, data are available on both maximum burst (anaerobic) swimming speed $\left(U_{\mathrm{mb}}\right)$ and maximum sustained (aerobic) swimming speed $\left(U_{\mathrm{ms}}\right)$ in some tuna species (Brill 1996, Korsmeyer et al. 1996, Syme \& Shadwick 2002). Unfortunately, data on bluefin tuna are scarce. Our goal was to provide estimates of swimming performance in tuna that are based on bluefin tuna where available. This approach has various limitations, because we can expect some interspecific difference between tuna species, and because our estimates of sustained swimming speeds are based on tuna smaller than those that we observed in the Strait of Gibraltar. Also, the temperature at which swimming performance was measured likely has an effect. These estimates thus need to be considered with caution. Nevertheless, they provide a frame of reference in order to evaluate the possibility that tuna of various sizes, chased by killer whales, may be pushed to the point of aerobic exhaustion during a prolonged pursuit at relatively high speed.

Estimates of maximum burst (anaerobic) swimming speeds. Burst swimming performance $\left(U_{\mathrm{mb}}\right)$ provides relatively precise limits of how fast a tuna can swim, but such a swimming speed is not sustainable for 


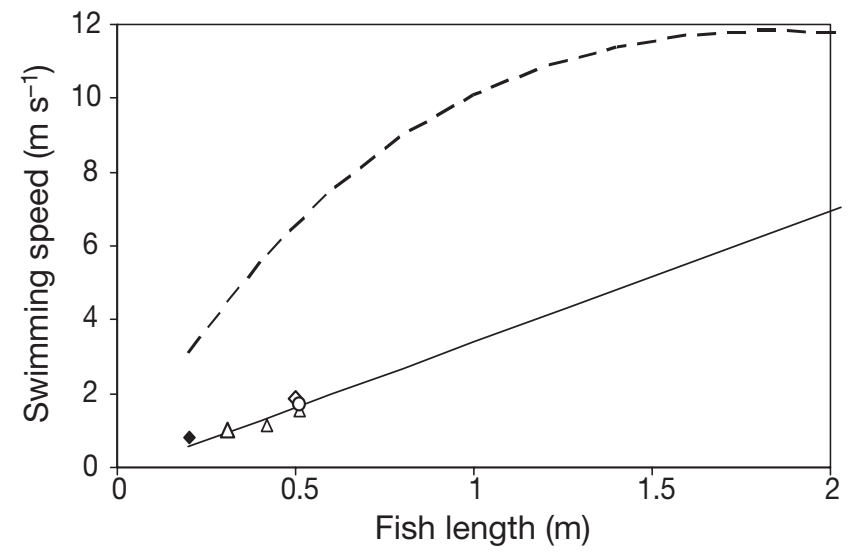

Fig. 2. Thunnus thynnus. Solid line: maximum aerobic swimming speed, based on estimates by Brill (1996) (average value of the range given in Fig. 2 of Brill 1996; O), Korsmeyer et al. $(1996 ; \diamond)$ and calculations $(\Delta)$ based on Syme \& Shadwick (2002) and data by Dewar \& Graham (1994) and Altringham \& Block (1997). : maximum speed attained by a $20 \mathrm{~cm}$ yellowfin tuna with a 30 min endurance (data from Sepulveda \& Dickson 2000). Dashed curve: estimates of maximum burst (anaerobic) swimming speeds for bluefin tuna (based on Wardle et al. 1989)

extended periods of time and requires anaerobic metabolism. Estimates of $U_{\mathrm{mb}}$ for bluefin tuna can be obtained by considering the data on the maximum muscle twitch rate, which are available for bluefin tuna comparable in size to those we observed (Wardle et al. 1989). According to Wardle (1975), $U_{\mathrm{mb}}$ can be calculated as:

$$
U_{\mathrm{mb}}=(A \times L) /(2 \times T)
$$

where $A$ is the stride length of the fish (i.e. the number of fish lengths travelled during a tail beat), $L$ is the length of the fish (in $\mathrm{m}$ ), and $T$ is the muscle contraction time (s). We used a stride length of 0.65 lengths, as this is the average value found in this species (Wardle et al. 1989). To scale tail beat frequency, which decreases with fish length, a $Q_{10 \mathrm{~cm}}$, i.e. the ratio of the muscle twitch frequency for each $10 \mathrm{~cm}$ difference in overall bluefin tuna length (Videler 1993), was calculated based on measurements by Wardle et al. (1989) of the twitch contraction of the anaerobic swimming muscles (at 0.45 lengths from the tip of the head) of bluefin tuna at $28^{\circ} \mathrm{C}$ of 2.00 , 2.26 and $2.53 \mathrm{~m}$ :

$$
Q_{10 \mathrm{~cm}}=(R 2 / R 1)^{10 /(L 2-L 1)}
$$

where $R 1$ and $R 2$ are the twitch frequencies of fish with lengths $L 1$ and $L 2$, respectively. For the 3 sizes investigated by Wardle et al. (1989), we obtained an average $Q_{10 \mathrm{~cm}}$ of 0.948 . This allowed us to estimate $U_{\mathrm{mb}}$ of bluefin tunas using Eq. (1), a stride length of 0.65 lengths, and a tailbeat frequency (i.e. $2 T$ ) based on a $Q_{10 \mathrm{~cm}}$ of 0.948 , following the equation (Videler 1993):

$$
\text { Tailbeat frequency }=K \times Q_{10 \mathrm{~cm}}{ }^{(L-R) / 10}
$$

where $K$ is the tailbeat frequency of the fish whose length is used as a 'reference', $L$ is the length of the fish for which tailbeat frequency is being estimated, and $R$ is the length of the reference fish. Using the tailbeat frequency in Eq. (1), we obtained $U_{\mathrm{mb}}$ as a function of tuna length (Fig. 2). The $U_{\mathrm{mb}}$ obtained should give a realistic range of values for bluefin tuna based on twitch duration even for smaller tuna. As a comparison, the twitch duration of a $0.4 \mathrm{~m}$ tuna, using our estimated $Q_{10 \mathrm{~cm}}$, should be about $21 \mathrm{~ms}$. This value is in the range of the twitch durations observed by Brill \& Dizon (1979) for skipjack tuna Katsuwonus pelamis at similar temperatures. Values of $U_{\mathrm{mb}}$ for tuna are expected to exceed those for other teleosts because of endothermy. Minimum twitch time is inversely related to temperature (Wardle 1975), although for a given temperature, twitch times for tuna and other teleosts are comparable (Videler 1993, Dewar \& Graham 1994).

Estimates of maximum sustained (aerobic) swimming speeds. Data on the $U_{\mathrm{ms}}$ of tuna in general are scarce, partly due to the difficulties of conducting such measurements, which normally require the use of swim tunnels, on large fish. Our estimates are based on work using a tuna from the same genus: the yellowfin tuna Thunnus albacares, using data from Korsmeyer et al. (1996) and Brill (1996), and calculations based on Syme \& Shadwick (2002) using oxygen consumption data from Dewar \& Graham (1994) and workloop data on Altringham \& Block (1997). A significant linear regression $(p<0.05)$ was obtained from these 5 estimates (Fig. 2):

$$
U_{\mathrm{ms}}=3.75 L-0.24 ; \mathrm{n}=5, \mathrm{r}^{2}=0.79, \mathrm{p}<0.05
$$

This regression estimates $U_{\mathrm{ms}}$ of tuna of various sizes ( 0.5 to $2 \mathrm{~m}$ ) to range between 3.3 and 3.5 lengths $\mathrm{s}^{-1}$, in line with previous work (Korsmeyer \& Dewar 2001). Estimation of swimming performance using this approach must be considered with caution due to (1) possible species-specific differences, (2) the limited size range (32 to $51 \mathrm{~cm}$ ) used, and (3) slight differences in temperature.

Extrapolation of the regression calculated beyond the size range of 32 to $51 \mathrm{~cm}$ is a potential source of error, although the relationships between length and sustained swimming speed are commonly linear (Videler 1993). Regarding temperature, swimming performance estimates have been carried out at 24 to $25^{\circ} \mathrm{C}$ (Brill 1996, Syme \& Shadwick 2002) and at $20^{\circ} \mathrm{C}$ (Wardle et al. 1989). Therefore, they may be overestimates of the swimming speeds bluefin tuna can attain in $16^{\circ} \mathrm{C}$ water. However, this effect of water tempera- 
ture differences is likely reduced by differences in endothermic abilities by bluefin compared to yellowfin tuna (Blank et al. 2007). The ability of tuna to maintain higher body temperature than the water increases with size (Sepulveda \& Dickson 2000). Wardle et al. (1989) recorded sea temperatures of $20^{\circ} \mathrm{C}$ and muscle temperatures at the twitch sites of $28^{\circ} \mathrm{C}$. Therefore, at a water temperature of about $16^{\circ} \mathrm{C}$, large tuna such as the ones we observed in the field may have been able to maintain muscle temperatures of around $24^{\circ} \mathrm{C}$.

Endurance vs. speed. As we lack data on maximum prolonged swimming speed ( $U_{\mathrm{mp}}$, usually measured as maximum swimming speed sustained for a relatively short time, on the order of minutes) we assumed a linear decrease from maximum swimming speed sustained for a $200 \mathrm{~min}$ period ( $U_{\mathrm{ms}}$ i Videler 1993) to $U_{\mathrm{mb}}$ (based on Eqs. 1, $2 \& 3$ ) and an endurance at $U_{\mathrm{mb}}$ of 0.01 min (Fig. 3). This approach may cause a slight overestimate of endurance for intermediate speeds, i.e. where $U_{\mathrm{mp}}$ would occur.

Endurance and swimming speed of killer whales. The aerobic performance of mammals is often evaluated on the basis of the maximal rate of oxygen uptake during exercise $\left(V_{\mathrm{O}_{2} \max }\right)$. To our knowledge, $V_{\mathrm{O}_{2} \max }$ has only been estimated for 1 cetacean species, the bottlenose dolphin Tursiops truncatus (Williams et al. 1993), which had a $V_{\mathrm{O}_{2} \max }$ ranging from 19.8 to $29.4 \mathrm{ml}$ $\mathrm{O}_{2} \mathrm{~kg}^{-1} \mathrm{~min}^{-1}$ in 2 exercising adult bottlenose dolphins. We estimated the maximum aerobic power output and consequently $U_{\mathrm{ms}}$ for a killer whale assuming a $V_{\mathrm{O}_{2} \max }$ ranging between 20 and $30 \mathrm{ml} \mathrm{O}_{2} \mathrm{~kg}^{-1} \mathrm{~min}^{-1}$ and compared it to the estimated metabolic rate of a killer whale according to swimming speed, using a conver-

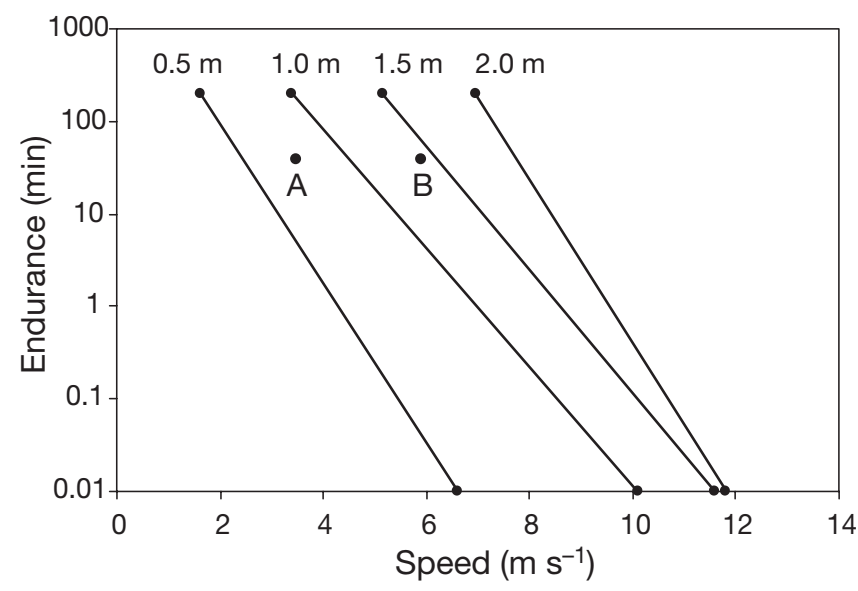

Fig. 3. Thunnus thynnus. Change in tuna endurance according to swimming velocity and size. Dot A indicates the mean swimming speed $\left(6 \mathrm{~m} \mathrm{~s}^{-1}\right)$ that killer whales were able to sustain for 30 min when chasing minke whales (Ford et al. 2005); Dot B indicates the observed mean swimming speed $(3.7 \mathrm{~m}$ $\mathrm{s}^{-1}$ ) of killer whales over a 30 min period when chasing bluefin tuna in the strait of Gibraltar sion factor of $0.23 \mathrm{~W}$ energy equivalent $\mathrm{l}^{-1} \mathrm{O}_{2}$ (Bartholomew 1977). The metabolic rate of a swimming killer whale $\left(M_{\mathrm{s}}, \mathrm{W}\right)$ was estimated as the sum of basal metabolic rate $\left(M_{\mathrm{B}}, \mathrm{W}\right)$ and the metabolic cost of locomotion $\left(M_{\mathrm{L}}, \mathrm{W}\right)$ to swim at a given speed:

$$
M_{\mathrm{s}}=M_{\mathrm{B}}+M_{\mathrm{L}}
$$

$M_{\mathrm{B}}$ was calculated according to the equation provided by Motani (2002), which suggested a 1.2-fold increase in metabolic rate of cetaceans compared to the Kleiber (1987) equation to take into account the increased $M_{\mathrm{B}}$ measured in cetacean species according to their mass (kg) (Williams et al. 1993):

$$
M_{\mathrm{B}}=6.45 \text { Mass }^{0.694}
$$

$M_{\mathrm{L}}$ was calculated according to the mean thrust power $\left(P_{\mathrm{T}}, \mathrm{W}\right)$ necessary to overcome the drag and corrected by the propulsive efficiency $(\eta)$. We used the $P_{\mathrm{T}}$ relationship provided by Fish (1998, see Eq. 6). $P_{\mathrm{T}}$ was expressed as a function of the drag coefficient $\left(C_{\mathrm{D}}\right)$, density of seawater $(\rho)$, body surface area of a killer whale $\left(S_{\mathrm{a}}\right)$ and swimming velocity $(U)$ :

$$
P_{\mathrm{T}}=0.5 \rho S_{\mathrm{a}} U^{3} C_{\mathrm{D}}
$$

The metabolic cost of locomotion was estimated according to the propulsive efficiency

$$
M_{\mathrm{L}}=P_{\mathrm{T}} / \eta
$$

with $\eta=0.88$ for speed higher than 1.2 body lengths $\mathrm{s}^{-1}$ for killer whales (see Fig. 7 in Fish 1998).

$C_{\mathrm{D}}$ was estimated according to the relationship between $C_{\mathrm{D}}$ and the Reynolds number (Re) experimentally assessed for killer whales (see Fig. 6 in Fish 1998), with Re being related to the whale length $(L, \mathrm{~m}), U$ and the kinematic viscosity of the water $\left(v=1.044 \times 10^{-6} \mathrm{~m}^{2} \mathrm{~s}^{-1}\right)$ :

$$
\begin{gathered}
\operatorname{Re}=L U / V \\
C_{\mathrm{D}}=6.35 \mathrm{Re}^{0.3719}
\end{gathered}
$$

Here we did not consider the potential effect of increased drag due to wave formation, as killer whales spent most of their time underwater at a depth where this drag is likely to be minimal, and they only breathe briefly at the surface.

$U_{\mathrm{ms}}$ was calculated for the value of $U$ allowing $M_{\mathrm{s}}$ to be equal to the maximum sustainable aerobic metabolic rate calculated from the $V_{\mathrm{O}_{2} \max }$ estimates.

Maximum sustainable swimming speed of killer whales. The $U_{\mathrm{ms}}$ of killer whales according to chase duration was calculated from 6 instances of prolonged, high speed chases of minke whales Balaenoptera acutorostrata in coastal waters of the northeast Pacific. Five of these were reported by Ford et al. (2005), and the sixth was documented in August 2005 (J. K. B. Ford unpubl. data). These values were compared to those obtained for the Strait of Gibraltar for killer whales 
chasing tuna and to the maximum aerobic swimming velocity estimates calculated from the metabolic models according to the killer whale $\mathrm{V}_{\mathrm{O}_{2} \max }$ estimates.

\section{RESULTS}

\section{Killer whale observations}

Searches for killer whales were conducted on 14 different occasions and were found and tracked on 5 occasions. Group size ranged between 4 and 9 killer whales $(5.7 \pm 0.5$, mean $\pm \mathrm{SE})$.

Active chases followed by a successful catch of a tuna were observed on 3 different occasions. Killer whales were generally spread out over the study area with a distance between foraging animals ranging between approximately 100 and $500 \mathrm{~m}$. Chases were initiated by a sudden change in swimming behaviour, with 1 individual starting to leap out of the water to breathe as it swam very rapidly in 1 direction, quickly followed by all other individuals converging in that direction.

Data on chase duration, the distance covered and mean swimming speed for each event are summarised in Table 1 (see also Fig. 1). The track lines tended to be fairly straight horizontally, although vertical excursions cannot be ruled out. Therefore, our estimates are likely to be underestimations of the actual speeds.

\section{Killer whale sustainable aerobic swimming speed}

Estimations of the sustainable aerobic swimming speed were conducted for an adult-sized killer whale (2300 $\mathrm{kg}$ and $5.6 \mathrm{~m}$ ) using the data provided by Fish (1998). This value is realistic compared to the estimated size range of killer whales observed in the Strait of Gibraltar and matches the $5.7 \mathrm{~m}$ measurement obtained from an old female killer whale found stranded in the spring of 2006. This female was a known individual that participated in the chasing events described in this paper.

Table 1. Orcinus orca. Observed swimming velocity of killer whales chasing bluefin tuna in the area of Barbate, Strait of Gibraltar

\begin{tabular}{|c|c|c|c|}
\hline Date & $\begin{array}{l}\text { hase duration } \\
\text { (min) }\end{array}$ & $\begin{array}{c}\text { Distance } \\
\text { covered }(\mathrm{m})\end{array}$ & $\begin{array}{l}\text { Sustained swimming } \\
\text { speed }\left(\mathrm{m} \mathrm{s}^{-1}\right)\end{array}$ \\
\hline 26 Apr 02 & 26 & 5550 & 3.6 \\
\hline 17 Apr 03 & 27 & 6280 & 3.9 \\
\hline 20 Apr 03 & 41 & 8560 & 3.5 \\
\hline Mean $\pm \mathrm{SE}$ & $31 \pm 8$ & $6800 \pm 1570$ & $3.7 \pm 0.2$ \\
\hline
\end{tabular}

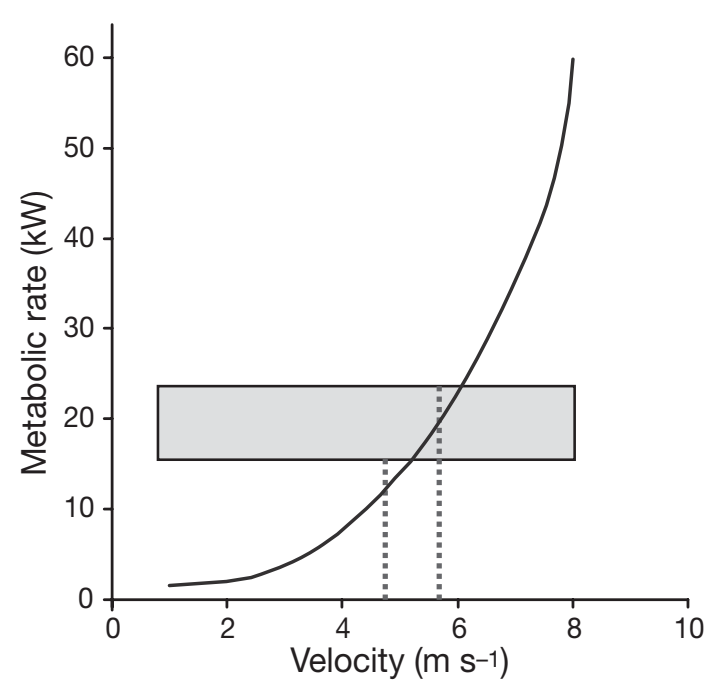

Fig. 4. Estimated metabolic rate (solid line) of killer whales according to swimming velocity; the range of the theoretical maximum aerobic metabolism rate (grey bar) and the corresponding maximum aerobic swimming speed (dotted lines; see text for details)

According to Eq. (2), $M_{\mathrm{B}}$ of a $2300 \mathrm{~kg}$ killer whale was estimated to be $1.40 \mathrm{~kW} \mathrm{~d}^{-1}$ (i.e. $0.60 \mathrm{~W} \mathrm{~kg}^{-1} \mathrm{~d}^{-1}$ ). Estimation of $M_{\mathrm{s}}$ of killer whale in relation to its swimming speed was done according to Eqs. (3) \& (4). The variation of $M_{\mathrm{s}}$ in relation to swimming velocity is shown in Fig. 4.

Assuming a $V_{\mathrm{O}_{2} \max }$ ranging between 20 and $30 \mathrm{ml} \mathrm{O}_{2}$ $\mathrm{kg}^{-1} \mathrm{~min}^{-1}$, the maximum aerobic metabolic rate was estimated to range between 15.6 and $23.4 \mathrm{~kW}$ (Fig. 4), i.e. 10 to 16 times the $M_{\mathrm{B}}$. The estimated maximum aerobic $M_{\mathrm{s}}$ corresponds to a $U_{\mathrm{ms}}$ ranging between 4.7 and $5.6 \mathrm{~m} \mathrm{~s}^{-1}$ according to the range of $V_{\mathrm{O}_{2} \max }$ used (Fig. 4).

The observed $U_{\mathrm{ms}}$ of killer whales calculated from the data obtained from when they were chasing minke whales decreased with chase duration according to the following equation (Fig. 5):

$$
y=19.24 x^{-0.36}, \mathrm{n}=6, \mathrm{r}^{2}=0.84, \mathrm{p}<0.01
$$

\section{Tuna vs. killer whale endurance}

To compare killer whale and tuna performance, we used our observed swimming speeds (Speed A: $3.7 \mathrm{~m}$ $\mathrm{s}^{-1}$ for about $30 \mathrm{~min}$ ) and the observed swimming speeds (Speed B: $6 \mathrm{~m} \mathrm{~s}^{-1}$ for about $30 \mathrm{~min}$ ) of killer whales pursuing minke whales. Fig. 4 shows the endurance curve for tuna, which is based on data from yellowfin and bluefin tuna compared to Speeds A and $\mathrm{B}$ for killer whales, showing that killer whales could catch tuna ranging between 0.8 and $1.5 \mathrm{~m}$ while remaining aerobic. 


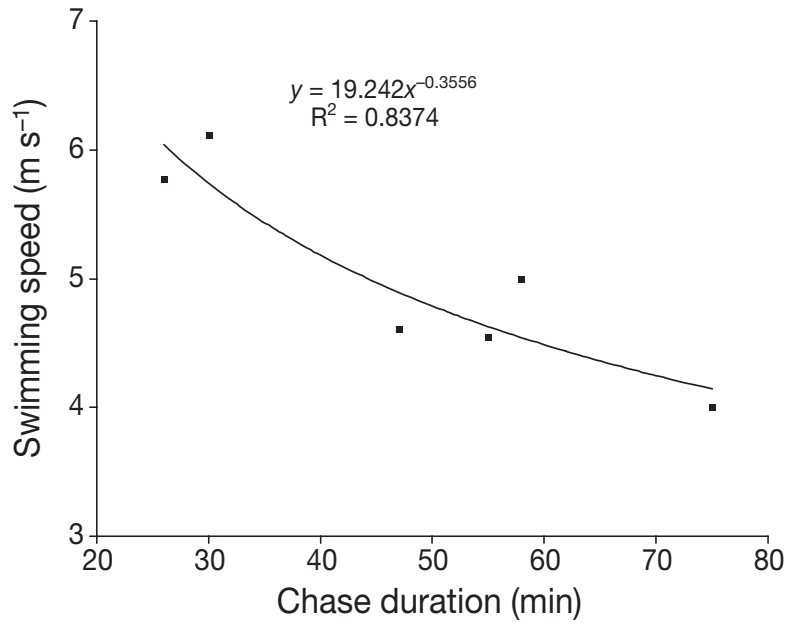

Fig. 5. Observed chase duration according to swimming speed of killer whales chasing minke whales in coastal northeastern Pacific waters. Data from Ford et al. (2005) and J. K. B. Ford (unpubl.)

\section{DISCUSSION}

Our data on killer whales pursuing tuna and theoretical calculations support the hypothesis that killer whales may use an endurance-exhaustion technique to catch small to medium-sized bluefin tuna (0.8 to $1.5 \mathrm{~m})$. Estimates of endurance in tuna (Fig. 2) suggest that the killer whale speed that we recorded $\left(3.7 \mathrm{~m} \mathrm{~s}^{-1}\right)$ would be sufficient to fatigue only relatively small tuna (i.e. about 0.8 to $1 \mathrm{~m}$ in length, weighing about $20 \mathrm{~kg}$ ), corresponding to the smallest individuals of the breeding component of the Mediterranean bluefin tuna population (Susca et al. 2001). However, our field observations are likely to be an underestimation of the actual swimming speed of the killer whales. This is because (1) the swimming path of both tuna and killer whales included vertical ascents and descents not measured in this study, and (2) we considered that the chase phase ended when all individuals were milling together, which means that we were actually estimating the swimming velocity of the slowest individuals (or those that came from farthest away). The highest swimming speed calculated using a theodolite to track free-ranging resident killer whales, not performing wave riding, was $5 \mathrm{~m} \mathrm{~s}^{-1}$ over a $20 \mathrm{~min}$ period (Kriete 1995), closer to the $6 \mathrm{~m} \mathrm{~s}^{-1}$ speed of killer whales chasing minke whales over $30 \mathrm{~min}$. Using values of 5 to $6 \mathrm{~m} \mathrm{~s}^{-1}$ of sustained speeds over $30 \mathrm{~min}$, killer whales are theoretically able to chase to exhaustion tuna that are up to about $1.5 \mathrm{~m}$ in length (i.e. 70 kg; Fig. 3).

The approach taken in this study to estimate tuna swimming performance has some limitations. First, our estimates of tuna speed must be taken with caution, as (1) they are extrapolated from small fish of a different species and (2) they are based on laboratory work. Also, our speed estimates are conservative, since they are based on work done at higher temperature and they assume a linear decrease from $U_{\mathrm{ms}}$ to $U_{\mathrm{mb}}$. Nevertheless, some field swimming speeds are available for bluefin tuna. These speeds never exceed 3.5 lengths $\mathrm{s}^{-1}$, which is the maximum aerobic swimming speed estimated based on laboratory work. Lutcavage et al. (2000) reported average speeds of North Atlantic bluefin tuna (136 to $340 \mathrm{~kg}$ ) of $1.6 \mathrm{~m} \mathrm{~s}^{-1}$, not exceeding $3.6 \mathrm{~m} \mathrm{~s}^{-1}$ (ca. 1.5 to 2 length s${ }^{-1}$ ) for more than $45 \mathrm{~min}$. Brill et al. (2002) observed juvenile bluefin tuna (74 to $106 \mathrm{~cm}$ in length) swimming at a maximum speed of $3.5 \mathrm{~m} \mathrm{~s}^{-1}$ (ca. 3.5 lengths s${ }^{-1}$ ) for brief periods. Similarly, the maximum speeds recorded in the field for yellowfin tuna (148 to $167 \mathrm{~cm}$ in length) are 4 to $4.2 \mathrm{~m} \mathrm{~s}^{-1}$ (ca. 2.5 to 2.8 lengths s${ }^{-1}$; Brill et al. 1999), although the duration of these bouts was not reported. Field measurements made by Davis \& Stanley (2002) indicated maximum swimming speeds of southern bluefin tuna Thunnus maccoyii (about $1 \mathrm{~m}$ long) around $3 \mathrm{~m} \mathrm{~s}^{-1}$ (ca. 3 lengths $\mathrm{s}^{-1}$ ), and estimated $U_{\mathrm{ms}}$ to be around 2.5 to $2.6 \mathrm{~m} \mathrm{~s}^{-1}$. Overall, these field data are in line with the hypothesis that killer whales can chase tuna until exhaustion when swimming at speeds between 3.7 and $6 \mathrm{~m} \mathrm{~s}^{-1}$.

The range of maximum sustainable velocities estimated by the model is higher than the mean observed swimming speed of killer whales chasing tuna in the Strait of Gibraltar. The discrepancy between the 2 values suggests that (1) our aerobic swimming speed estimates are too high (e.g. lower $\mathrm{V}_{\mathrm{O}_{2} \mathrm{max}}$, although this is unlikely as our estimate matches the observed swimming speed of killer whales chasing minke whales); (2) killer whales adjust their swimming velocity in relation to the size of the tuna they chase to remain aerobic and consequently reduce the metabolic cost of the chase; or (3) our field observations underestimated the actual swimming velocity (see above). As we were unable to precisely assess the size of the tuna that killer whales caught in these situations, we cannot test the likelihood of these respective hypotheses.

Our results suggest that killer whales catch relatively small tuna by chasing them to exhaustion. The question remains as to whether killer whales can overtake tuna by employing bursting and manoeuvring at high speed. Although available data show that tuna are relatively poor manoeuverers (Blake et al. 1995), the scaling of unsteady swimming (Domenici 2001) is such that the performance of killer whales, which are 2 to 3 times longer than tuna, is expected to be poorer than that of tuna. Previous research has considered turning radius, turning rate and acceleration as the main indicators of unsteady swimming performance relevant to predator-prey encounters (see Domenici 
2001 for a review). Data on turning radius show that the standardised turning radius (minimum values) of tuna (data on Thunnus albacares, Blake et al. 1995) and killer whales (Fish 2002) are 0.2 and 0.11 lengths, respectively. This corresponds to $0.2-0.4 \mathrm{~m}$ for tuna between 1 and $2 \mathrm{~m}$ in length, and $0.55 \mathrm{~m}$ for a $5 \mathrm{~m}$ killer whale. Similarly, the scaling of turning rates (Domenici 2001) suggests that the large size difference between tuna and killer whale implies a slower turning rate in the latter. While data on turning rates in large tuna are not available, the turning rate of a $0.3 \mathrm{~m}$ yellowfin tuna is 459 degrees $\mathrm{s}^{-1}$ (calculated from Blake et al. 1995, Domenici 2001). Using the scaling provided by Domenici (2001), this implies a turning rate around 200 degrees $\mathrm{s}^{-1}$ in $1.5 \mathrm{~m}$ tuna. Data on killer whales show values around 100 to 150 degrees s${ }^{-1}$ (Fish 2002). While no data are available on the acceleration of these 2 species, both theoretical scaling considerations and data on other species suggest that cetaceans tend to have lower absolute accelerations than fish (Domenici 2001).

The above considerations suggest that large aquatic mammals, such as killer whales, are at a disadvantage when trying to use burst swimming and manoeuvring to catch prey that are smaller than they are, such as tuna and other fish species. These potential mechanical disadvantages in performance, mostly due to scaling laws, may imply alternative techniques such as endurance chasing instead of burst swimming. Larger tuna may be inaccessible unless additional methods are used, such as cooperative herding of the prey by killer whale pod members against natural or artificial obstacles. In addition, tuna are schooling fish; therefore, killer whales are likely to chase schools of tuna, and the outcome of these chases could be the capture of several individuals. One of the natural obstacles of the study area is the shore, and in 1 of the 3 pursuits, killer whales were observed to chase tuna toward the shore line, where they caught the fish. This behaviour was reported by local fishermen from the Barbate area, where local people walk along the beach during the 'killer whale season' to collect freshly stranded tuna. Artificial obstacles include the trap nets (Almadraba) set in the area to catch migrating tuna. Pelagic marine environments do not usually offer refuges to their inhabitants, and therefore predators may be able to chase their prey to the point of exhaustion (Domenici 2003). In these open environments, fish may take refuge at depths unreachable by their predators. This may be especially effective in the case of killer whales, which are not known to dive to depths much exceeding $300 \mathrm{~m}$ (Bowers \& Henderson 1972). Killer whales may hunt in the observed area due to the relatively shallow water $(<100 \mathrm{~m})$, which would prevent bluefin tunas from escaping by performing deep dives. Depths within the study area are well within the diving performance of killer whales (Baird et al. 2005). Our observations indicate that tuna did not change direction when chased, and this may be related to the group hunting tactic of killer whales (Domenici 2001).

In summary, the present study suggests that similar to some terrestrial carnivores such as African hunting dogs Lycaon pictus, which pursue their prey until it drops from exhaustion (Alexander 2002), killer whales rely on endurance to catch tuna rather than on sprinting speed. However this 'chase' technique may be effective for catching only small to medium-sized bluefin tuna, while larger fish (>1.5 m) may be too fast. This finding also suggests that killer whales preying on tuna may rely on other techniques to catch larger individuals. Furthermore, the results suggest that the energetic cost of these chases is extremely high. In this context, fisheries can potentially provide easy access to larger tuna, which are otherwise extremely difficult to catch, through depredation of fish caught on long lines, drop lines or by entering directly into trap nets.

Acknowledgements. This project was possible thanks to the life project LIFE02NAT/E/8610, coordinated by the Spanish Cetacean Society. We thank IFAW for providing the software Logger 2000 and CIRCé for providing logistical support for the field work. Thanks also to all companies that manage the Alamadraba fisheries in the area. We thank J. Videler, F. Fish, P. Bushnell, and R. Shadwick for various discussions and suggestions on this manuscript. The comments of 3 anonymous referees which greatly improved the quality of this paper are also appreciated.

\section{LITERATURE CITED}

Alexander RM (2002) Principles of animal locomotion. Princeton University Press, Princeton, NJ

Altringham JD, Block BA (1997) Why do tuna maintain elevated slow muscle temperatures? Power output of muscle isolated from endothermic and ectothermic fish. J Exp Biol 200:2617-2627

Altringham JD, Shadwick RE (2001) Swimming and muscle function. In: Block BA, Stevens ED (eds) Tuna: physiology, ecology and evolution. Academic Press, San Diego, CA, p 313-344

Baird RW, Hanson MB, Dill LM (2005) Factors influencing the diving behaviour of fish-eating killer whales: sex differences and diel and interannual variation in diving rates. Can J Zool 83:257-267

Bartholomew GA (1977) Body temperature and energy metabolism. In: Gordon MS (ed) Animal physiology: principles and adaptations. MacMillan Publishing, New York, p 364-449

Blake RW, Chatters LM, Domenici P (1995) Turning radius of yellowfin tuna (Thunnus albacares) in unsteady swimming manoeuvres. J Fish Biol 46:536-538

Blank JM, Farwell CJ, Morrissette JM, Schallert RJ, Block BA (2007) Influence of swimming speed on metabolic rates of juvenile Pacific bluefin tuna and yellowfin tuna. Physiol Biochem Zool 80:167-177 
Block BA, Stevens ED (eds) (2001) Tuna: physiology, ecology and evolution. Academic Press, San Diego, CA

Bowers CA, Henderson RS (1972) Project Deep Ops: deep object recovery with pilot and killer whales. Document NUC TP 306, Naval Undersea Center, San Diego, CA

Brill RW (1987) On the standard metabolic rate of tropical tunas, including the effect of body size and acute temperature change. Fish Bull 85:25-35

Brill RW (1996) Selective advantages conferred by the high performance physiology of tunas, billfishes and dolphin fish. Comp Biochem Physiol 113A:3-15

Brill RW, Bushnell RW (2001) The cardiovascular system of tuna. In: Block BA, Stevens ED (eds) Tuna: physiology, ecology and evolution. Academic Press, San Diego, CA, p 79-120

Brill RW, Dizon AE (1979) Effect of temperature on isotonic twitch of white muscle and predicted speeds of skipjack tuna, Katsuwonus pelamis. Environ Biol Fishes 4(3):199-205

Brill RW, Block BA, Boggs $\mathrm{CH}$, Bigelow KA, Freund EV, Marcinek DJ (1999) Horizontal movements and depth distribution of large adult yellowfin tuna (Thunnus albacares) near the Hawaiian Islands, recorded using ultrasonic telemetry: implications for the physiological ecology of pelagic fishes. Mar Biol 133:395-408

Brill R, Lutcavage M, Metzger G, Bushnell P, Arendt M, Lucy G, Watson C, Foley D (2002) Horizontal and vertical movements of juvenile bluefin tuna (Thunnus thynnus), in relation to oceanographic conditions of the western North Atlantic, determined with ultrasonic telemetry. Fish Bull 100:155-167

Bushnell PG, Brill RW (1991) Responses of swimming skipjack (Katsuwonus pelamis) and yellowfin (Thunnus albacares) tunas exposed to acute hypoxia, and a model of their cardio-respiratory function. Physiol Zool 64:787-811

Davis TLO, Stanley CA (2002) Vertical and horizontal movements of southern bluefin tuna (Thunnus maccoyii) in the Great Australian Bight observed with ultrasonic telemetry. Fish Bull 100:448-465

De Stephanis R (2004) Distribución especial de cetáceos en el Estrecho de Gibraltar en época estival relacionada con la oceanografía. MSc thesis, University of Cadiz

Dewar H, Graham JB (1994) Studies of tropical tuna swimming performance in a large water tunnel. I. Energetics. J Exp Biol 192:13-31

Dickson KA (1994) Unique adaptations of the metabolic biochemistry of tunas and billfishes for life in the pelagic environment. Environ Biol Fishes 42:65-97

Domenici P (2001) The scaling of locomotor performance in predator-prey encounters: from fish to killer whales. Comp Biochem Physiol A 131:169-182

Domenici P (2003) Habitat, body design and the swimming performance of fish. In: Bels VI, Gasc JP, Casinos A (eds) Vertebrate biomechanics and evolution. Bios Scientific Publishers, Oxford, p 137-160

Domenici P, Batty RS, Simila T, Ogam EK (2000) Killer whales (Orcinus orca) feeding on schooling herring (Clupea harengus) using underwater tail slaps: Kinematic analyses of field observations. J Exp Biol 202:283-294

Fish FE (1993) Power output and propulsive efficiency of swimming bottlenose dolphins (Tursiops truncatus). J Exp Biol 185:179-193

Fish FE (1998) Comparative kinematics and hydrodynamics of odontocete cetaceans: morphological and ecological correlates with swimming performance. J Exp Biol 201: $2867-2877$

Fish FE (2002) Balancing requirements for stability and manoeuvrability in cetaceans. Integr Comp Biol 42:85-93

Fish FE, Innes S, Ronald K (1988) Kinematics and estimated thrust production of swimming harp and ringed seals. J Exp Biol 137:157-173

Ford JKB, Ellis G, Matkin DM, Balcomb KC, Briggs D, Morton AB (2005) Killer whale attacks on minke whales: prey capture and antipredator tactics. Mar Mamm Sci 21:603-618

Guinet C (1992) Comportement de chasse des orques (Orcinus orca) autour des Iles Crozet. Can J Zool 70:1656-1667

Heyning JE, Dahlheim ME (1988) Orcinus orca. Mamm Species 304:1-9

Kleiber M (1987) The fire of life. RE Krieger Publishing, Malabare, FL

Korsmeyer KE, Dewar H (2001) Anatomical and physiological specializations for endothermy. In: Block BA, Stevens ED (eds) Tuna: physiology, ecology and evolution. Academic Press, San Diego, CA, p 35-78

Korsmeyer KE, Dewar H, Lai NC, Graham JB (1996) Tuna aerobic swimming performance: physiological and environmental limits based on oxygen supply and demand. Comp Biochem Physiol 113B:45-56

Kriete B (1995) Bioenergetics in the killer whale, Orcinus orca. PhD dissertation, University of British Columbia, Vancouver

Lutcavage ME, Brill RW, Skomal GB, Chase BC, Goldstein JL, Tutein J (2000) Tracking adult North Atlantic bluefin tuna (Thunnus thynnus) in the northwestern Atlantic using ultrasonic telemetry. Mar Biol 137:347-358

Maresh JL, Fish FE, Nowacek DP, Nowacek SM, Wells RS (2004) High performance turning capabilities during foraging by bottlenose dolphins (Tursiops truncatus). Mar Mamm Sci 20:498-509

Motani R (2002) Swimming speed estimation of extinct marine reptiles: energetic approach revisited. Paleobiology 28:251-262

Sepulveda C, Dickson KA (2000) Maximum sustainable speeds and cost of swimming in juvenile kawakawa tuna (Euthynnus affinis) and chub mackerel (Scomber japonicus). J Exp Biol 203:3089-3101

Susca V, Corriero A, Delflorio M, Bridges CR, De Metrio G (2001) New results on the reproductive biology of the bluefin tuna (Thunnus thynnus) in the Mediterranean. Col Vol Sci Pap ICCAT 52:745-751

Syme DA, Shadwick RE (2002) Effects of longitudinal body position and swimming speed on mechanical power of deep red muscle from skipjack tuna (Katsuwonus pelamis). J Exp Biol 205:189-200

Videler JJ (1993) Fish swimming. Chapman \& Hall, London

Wardle CS (1975) Limits of fish swimming speed. Nature 255: $725-727$

Wardle CS, Videler JJ, Arimoto T, Franco JM, He P (1989) The muscle twitch and the maximum swimming speed of giant bluefin tuna, Thunnus thynnus L. J Fish Biol 35:129-137

Webb PW (1984) Form and function in fish swimming. Sci Am 251:58-68

Williams TM, Friedl WA, Haun JE (1993) The physiology of bottlenose dolphins (Tursiops truncatus): heart rate, metabolic rate and plasma lactate concentration during exercise. J Exp Biol 179:31-46 